\title{
Refuge
}

Canada's Journal on Refugees

Revue canadienne sur les réfugiés

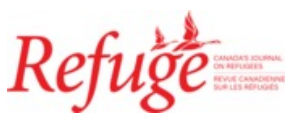

\section{Australia's Private Refugee Sponsorship Program: Creating Complementary Pathways Or Privatising Humanitarianism?}

\section{Asher Lazarus Hirsch, Khanh Hoang and Anthea Vogl}

Volume 35, Number 2, 2019

Private Sponsorship in Canada

URI: https://id.erudit.org/iderudit/1064823ar

DOI: https://doi.org/10.7202/1064823ar

See table of contents

Publisher(s)

Centre for Refugee Studies, York University

ISSN

0229-5113 (print)

1920-7336 (digital)

Explore this journal

Cite this article

Hirsch, A., Hoang, K. \& Vogl, A. (2019). Australia's Private Refugee Sponsorship Program: Creating Complementary Pathways Or Privatising Humanitarianism? Refuge, 35(2), 109-122. https://doi.org/10.7202/1064823ar
Article abstract

This article provides the first history and critique of Australia's private refugee sponsorship program, the Community Support Program (CSP). As more countries turn to community sponsorship of refugees as a means to fill the "resettlement gap," Australia’s model provides a cautionary tale. The CSP, introduced in 2017, does not expand Australia's overall resettlement commitment but instead takes places from within the existing humanitarian resettlement program. The Australian program charges sponsors exorbitant application fees, while simultaneously prioritizing refugees who are "job ready," with English-language skills and ability to integrate quickly, undermining the principle of resettling the most vulnerable. As such, we argue that the CSP hijacks places from within Australia's humanitarian program and represents a market-driven outsourcing and privatization of Australia's refugee resettlement priorities and commitments.
Copyright (c) Refuge: Canada's Journal on Refugees, 2019

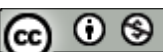

This document is protected by copyright law. Use of the services of Érudit (including reproduction) is subject to its terms and conditions, which can be viewed online.

https://apropos.erudit.org/en/users/policy-on-use/ 


\title{
Australia's Private Refugee Sponsorship Program: Creating Complementary Pathways or Privatizing Humanitarianism?
}

\author{
ASHER HIRSCH, KHANH HOANG, and ANTHEA VOGL
}

\section{Abstract}

This article provides the first history and critique of Australia's private refugee sponsorship program, the Community Support Program (CSP). As more countries turn to community sponsorship of refugees as a means to fill the "resettlement gap," Australia's model provides a cautionary tale. The CSP, introduced in 2017, does not expand Australia's overall resettlement commitment but instead takes places from within the existing humanitarian resettlement program. The Australian program charges sponsors exorbitant application fees, while simultaneously prioritizing refugees who are "job ready," with English-language skills and ability to integrate quickly, undermining the principle of resettling the most vulnerable. As such, we argue that the CSP hijacks places from within Australia's humanitarian program and represents a market-driven outsourcing and privatization of Australia's refugee resettlement priorities and commitments.

\section{Résumé}

Cet article offre la première histoire et critique du programme de parrainage privé des réfugiés en Australie, le Community Support Program (CSP). Alors que de plus en plus de pays se tournent vers le parrainage communautaire pour combler les besoins en matière de réinstallation, le modèle australien tient lieu de mise en garde. Le CSP, introduit en 2017, nétend pas les engagements de l'Australie en matière de réinstallation, mais accapare des places au sein du programme humanitaire de réinstallation déjà existant. Le programme australien impose aux parrains des frais de demande exorbitants tout en donnant la priorité aux réfugiés qui sont prêts à occuper un emploi, qui ont des compétences linguistiques en anglais et qui sont capables de s'intégrer rapidement, minant ainsi le principe de réinstallation des plus vulnérables. Nous soutenons que le CSP détourne des places du programme humanitaire australien et représente une sous-traitance axée sur le marché ainsi qu'une privatisation des priorités et engagements de l'Australie en matière de réinstallation.
(C) Asher Hirsch, Khanh Hoang, and Anthea Vogl, 2019. This open-access work is licensed under a Creative Commons Attribution-NonCommercial 4.0 International Licence, which permits use, reproduction, and distribution in any medium for non-commercial purposes, provided the original authorship is credited and the original publication in Refuge: Canada's Journal on Refugees is cited.
Cette ouvre en libre accès fait lobjet d'une licence Creative Commons Attribution-NonCommercial 4.0 International License, laquelle autorise l'utilisation, la reproduction et la distribution de l’euvre sur tout support à des fins non commerciales, pourvu que l'auteur ou les auteurs originaux soient mentionnés et que la publication originale dans Refuge: revue canadienne sur les réfugiés soit citée. 


\section{Introduction}

At a time when the global gap between refugee resettlement needs and resettlement places made available by governments is widening, countries around the world are increasingly looking to community sponsorship to expand and supplement their refugee resettlement. In September 2016 a meeting of un General Assembly states resulted in the New York Declaration of Refugees and Migrants, wherein member states agreed to negotiate a Global Compact on Refugees in order to strengthen the international refugee regime's response to large refugee movements. The resulting final draft of the Global Compact on Refugees calls upon states "to establish private or community sponsorship programs that are additional to regular resettlement" in order to provide timely access to durable solutions for refugees. ${ }^{1}$ Following from the New York Declaration, a number of states are experimenting with community sponsorship programs, following in the footsteps of Canada's long-running program, including the United Kingdom, Ireland, New Zealand, Argentin, and some in the European Union.

In the lead-up to the New York Declaration, Australia confirmed its intentions to join this list and implement a permanent community sponsorship program. Australian Prime Minister Malcolm Turnbull announced that "in addition to our existing programs, Australia will ... create new pathways for refugees to resettle in Australia through the establishment of 1000 places under a Community Support Programme, where communities and businesses can sponsor applications and support new arrivals." ${ }^{2}$

This article provides the first detailed overview of Australia's historical and current approaches to community sponsorship. In particular, it addresses the current Community Support Program (CSP), which formally began in late 2017, and the Community Proposal Pilot (CPP), which began in 2013 and preceded the CSP. As well, it traces Australia's prior experimentation in this policy area, namely the Community Refugee Settlement Scheme (CRSs), which ran for almost twenty years from 1979 to 1997. In doing so, we argue that potentials of private sponsorship cannot be assessed independently of the details and national context of specific sponsorship programs. The manner in which sponsorship programs are framed and promoted by nation states, as well as the design, are factors that determine the value of sponsorship programs, particularly when such programs are framed as "complementary" pathways to traditional government-led resettlement.

While the CSP provides a much-needed counterpoint to Australia's infamous Operation Sovereign Borders-a "military-led" border control program centred upon securitization and the absolute control of refugee movements 3 there are problematic policies built into the program, which include a lack of additionality; ${ }^{4}$ prohibitively high visa application charges and processing fees; discriminatory selection criteria; and lack of community engagement in the design and participation of the program. Read together, Australia's CSP is best understood as an exercise in the privatization of resettlement responsibilities and costs that ultimately reduces the Australian government's overall commitment to resettlement. The use of private funding to directly replace government-funded places, and the preference for "workready" refugees, which characterize the CSP, entail that the Australian program cannot be characterized as creating a complementary pathway to resettlement. Instead, we argue that in its current form it represents a market-driven outsourcing and privatization of the existing refugee program. This view is echoed in the government's own framing of the program, which it has promoted not only as "cost saving," but as a revenue-raising measure.

We argue that the Australian experience-in particular, the CSP-provides cause for pause and caution. While community sponsorship has considerable untapped potential in Australia, the parameters of community sponsorship schemes need to be carefully crafted and managed to ensure that governments do not use sponsorship to shift the cost of long-standing public programs for resettling refugees onto private actors, further entrench controlled migration as a precondition to offering protection to refugees, and shift resettlement focus away from the most vulnerable refugeesrisks that are inherent within the current CsP framework.

In the first part of this article, we explain the history, design, and focus of the crss and the motivation for this program, which provides important background to contemporary private sponsorship in Australia. The following sections outline and critique the CPP and the CSP, with a focus on the political context of control and deterrence of refugee arrivals, into which both programs were introduced. Finally, we highlight the risks of "exporting" the Australian model to other jurisdictions and examine the sustained communityand sector-based efforts to promote reform and improvement of the CSP in Australia.

\section{The Community Refugee Settlement Scheme}

While there is a vast literature on refugee resettlement in Australia, ${ }^{5}$ there is little mention of Australia's historical use of community sponsorship to support the resettlement of refugees and humanitarian entrants. While Australia may appear as a newcomer to community sponsorship programs, it has, in fact, a significant history with community sponsorship through the Community Refugee Settlement Scheme (CRss) that ran from 1979 to 1997. The CRSs, which helped to settle and integrate over 30,000 refugees in Australia, was a critical part of Australia's response to the Indochinese 
refugee crisis and a key feature of Australia's resettlement policies in the 1980 ond early 199 os. $^{6}$

The program was introduced on 30 October 1979 by the minister for immigration, Michael MacKellar, following a recommendation of the Australian Refugee Advisory Council. ${ }^{7}$ MacKellar had floated the idea of a community sponsorship program a year prior, as part of a reconsideration of Australia's strategic response to the Indochinese refugee crisis, in particular the resettlement of Vietnamese refugees from countries of first asylum. ${ }^{8}$ A particular challenge facing the Australian government at the time was that resettled refugees were accommodated and processed in government-run hostels and migrant centres before being dispersed into the wider community. ${ }^{9}$ Not only were these migrant centres and hostels costly to run, they also couldn't cope with large numbers of Vietnamese refugee arrivals whom the Australian government had agreed to resettle. MacKellar thus identified a "need to cope with the transition from hostels to the community." ${ }^{\circ}$

At its core, the CRSs was a mechanism to allow refugees to bypass government-run migrant centres and hostels and be moved directly into the Australian community, into the care of those members of the local community who had undertaken to provide assistance. The aims of the CRss were to:

- give members of the community an opportunity to become directly involved in the settlement of refugees and contribute to their integration;

- provide an alternative means of settlement for refugees who have a capacity to integrate quickly into the Australian community;

- encourage greater awareness of the government's refugee resettlement program; and

- achieve a more geographically dispersed settlement of refugees through the Australian community. ${ }^{11}$

Initially the CRss was available only to support Vietnamese refugees, but it was later expanded to cover Eastern European and Latin American refugees. ${ }^{12}$ The CRSs was open to participation by established voluntary agencies (including religious organizations), organized groups of individuals, employers, and individuals as supporters. It was envisaged that the majority of offers of support would come from voluntary agencies, but offers from individuals who could demonstrate a capacity to fulfill sponsorship obligations would also be considered. ${ }^{13}$ Individuals were required to have "back-up" support from an established group or organization, in the event that they could not fulfill their responsibilities. ${ }^{14}$ Initially sponsors could also nominate a preference for sponsoring a specific ethnic group, family size and composition, or specific employment or linguistic skills, but they were not able to propose a refugee by name for CRss sponsorship. ${ }^{15}$

Applications to participate in the scheme were vetted by the Community Refugee Resettlement Committee. ${ }^{16}$ The committee had to be satisfied on both the eligibility of the persons or group to participate in the CRSS as sponsors, as well as the viability of the support offer. Whether a person or group was deemed eligible to participate as a sponsor depended on factors that included the standing of the group or organization, the level of financial resources, and their demonstrated capacity to assist refugees including previous experience with refugee settlement and community welfare matters. The viability of offers was tested against a range of criteria, which were strongly focussed on the quality and security of the resettlement assistance being offered. The criteria included the period of support offered, the suitability of accommodation, the avoidance of isolation, the prospect of securing employment for the refugees in the area, and the provision of English-language training. While, in theory, the CRSs allowed individuals, businesses, and community groups to provide sponsorship, as noted below the majority of sponsorships came from family members who used the CRSs to facilitate family reunion. The other major source of sponsors derived from church-based or ethnic community groups. ${ }^{17}$ There is very little evidence that businesses were involved in the crss.

The Australian government was responsible for processing and transporting refugees from abroad to Australia, and to the locality where they were to receive CRSs support. Entrants under the CRSS were selected from a pool of refugees who had passed the government's "normal refugee selection criteria." 18 Beyond meeting the criteria for a refugee, considerable discretion was left to decision-makers at overseas posts to refer resettled refugees for CRSs support. At one end of the spectrum, nuclear families and groups who could speak English with reasonable employment prospects were always "well received." 19 In particular, when Australia introduced the Special Humanitarian Program (sHP) in 1981, many of these applications for entry also included offers of CRss support. The SHP allowed individuals to nominate family members for resettlement to Australia. To be eligible for the SHP, applicants were required to "demonstrate a personal claim on Australia by virtue of having close relatives settled here, close former ties with Australia or, for a small number, a strong and well-established community which [was] wellorganised and able and willing to provide all necessary settlement support." ${ }^{\circ}$ By 1983 some 60 per cent of CRss cases were family reunion cases, whereby CRss offers of support upon arrival were attached to refugee and sHP cases (in effect a form of co-sponsorship). ${ }^{21}$ While it is beyond the scope of this article to provide a full analysis, the use of CRSs as a family reunification program was not well received by the Australian government. In essence, the government considered that the CRSs had morphed from a settlement support program into a "queue-jumping" or a "de facto sponsorship" 
Table 1. Refugees supported through the CRSS, 1980-1993

CRSS as an approximate percentage of

\begin{tabular}{|c|c|c|c|}
\hline Year & CRSS & Total & total refugee and humanitarian intake \\
\hline 1980 & 766 & 19,954 & $4 \%$ \\
\hline 1981 & 1569 & 22,545 & $7 \%$ \\
\hline 1982 & 2550 & 21,917 & $12 \%$ \\
\hline 1983 & 2242 & 17,054 & $13 \%$ \\
\hline 1984 & 2240 & 15,485 & $14 \%$ \\
\hline 1985 & 2191 & 14,207 & $15 \%$ \\
\hline 1986 & 2154 & 11,700 & $18 \%$ \\
\hline 1987 & 2509 & 11,291 & $22 \%$ \\
\hline 1988 & 2552 & 11,392 & $22 \%$ \\
\hline 1989 & 3480 & 11,309 & $31 \%$ \\
\hline 1990 & 3885 & 12,415 & $31 \%$ \\
\hline 1991 & 3580 & 11,284 & $32 \%$ \\
\hline 1992 & 2733 & 12,009 & $23 \%$ \\
\hline 1993 & 3419 & 11,845 & $29 \%$ \\
\hline
\end{tabular}

Sources: Data derived from Department of Home Affairs, Historical Migration Statistics (May 2018); Department of Immigration, Local Government and Ethnic Affairs, "Our Good Friends": Australians Helping Refugees to a New Life (Sydney: Department of Immigration, Local Government and Ethnic Affairs, 1991), 62.

mechanism that circumvented uniform management of the humanitarian program. ${ }^{22}$

At the other end of the spectrum, the CRss also placed special emphasis on "doubly-disadvantaged cases" including "the disabled, single parent families, and families who have individuals who, for some other reason, have a higher than usual chance of encountering settlement difficulties."23 In such doubly disadvantaged cases, a CRss referral might "change the balance in favour of approving the application" for resettlement to Australia. ${ }^{24}$

Another important feature of the CRss, especially in light of Australia's current program, was the level of government support provided to sponsorship groups. Support groups were eligible for government support for second and subsequent entrants, initially $\$ 170$ for an individual and $\$ 450$ for a family of four, and $\$ 70$ for each additional family member in $1983 .{ }^{25}$ Support groups could also benefit from taxation concessions in the form of income tax deductions for donations and exemptions from sales tax for goods purchased to support the settlement of entrants. Further, sponsorship groups were provided with training by the Department of Immigration and Ethnic Affairs, and a quarterly newsletter was published to allow sponsors from each different state and territory to share their experiences.
The first group of refugees to be supported under the scheme were a group of twenty families, who were settled in Whyalla under the auspices of the St. Theresa's Refugee Resettlement Committee. ${ }^{26}$ In the first eight months of its operation, 766 Indochinese refugees were resettled under the scheme. ${ }^{27}$ Between 1980 and 1993, the CRss helped to settle over 30,00o refugees in Australia and, at its peak, accounted for approximately 32 per cent of Australia's overall refugee and humanitarian intake (see table 1).

While the crss has not been subjected to rigorous academic study, a number of independent and government initiated reports pointed to the important role that the scheme played in facilitating the successful settlement of refugees in Australia. ${ }^{28}$ The largest study of the CRSs was conducted by MSJ Keys Young in $1981,{ }^{29}$ commissioned by the Australian government and based on interviews with 157 refugee families and sponsors around Australia. The report painted the CRSS in a very positive light: "It is clear that the CRSS operates successfully to assist refugees in settling in Australia. It has demonstrated that the genuine care and the great time and effort offered by community people ensures that the refugees make use of all the services available in their communities."30

The report also highlighted deficiencies with the operation of the scheme, including that matching refugees to sponsors, 
especially in rural areas, resulted in some refugees not being able to access appropriate services and employment opportunities. It also identified that some sponsor groups were not adequately prepared for the level of financial support required, and that sponsors' overbearing behaviour caused difficulties. ${ }^{31}$

Other reports later in the life of CRss also raised concerns about its implementation. For example, a 1998 report by the Australian National Audit Office (ANAO) highlighted deficiencies in the manner in which the CRss was implemented by the Department of Immigration and Multicultural Affairs. The ANAO report found that the department's "procedures for review and accountability of [sponsorship] groups are not working well." ${ }^{2}$ In particular, the department had not properly followed its own procedures for accepting groups as CRSS sponsors, and, as the result of resource constraints, had not monitored sponsorships to the required level. 33 Such concerns were also highlighted by the Refugee Council of Australia (RCOA), which noted that the expectations and responsibilities of CRss groups had grown, while logistical and training support from the department had been reduced in response to funding restrictions. 34

The CRSs was formally disestablished in 1997 and replaced by the Integrated Humanitarian and Settlement Strategy (IHSS). 35 The IHSS represented a departure from previous settlement policies, as it aimed for entrants to attain self-sufficiency as soon as possible rather than encouraging dependency. Under the IHSS, settlement services were contracted out to private service providers who were responsible for providing intensive initial settlement support to all humanitarian entrants. ${ }^{36}$ Many of the services available under the IHSS were precisely the types of support previously provided by community sponsors. ${ }^{37}$ However, community groups were allowed to contribute in a volunteer capacity to complement IHss services and were provided with training to do so. ${ }^{38}$ After the cessation of the CRss, the sponsorship of refugees for entry into Australia continued informally through the SHP.

Overall, the available literature suggests that the CRSS was a positive component of Australia's resettlement policy. While the CRSs was not a sponsorship scheme for entry into Australia, it provided a post-settlement support mechanism and one that enabled the Australian government to resettle refugees throughout the country at a relatively low cost. Importantly, the CRss facilitated and complemented Australia's resettlement program that was at the time largely focused on vulnerable refugees and family reunification.

\section{Australia's Contemporary Sponsorship Programs}

Given the breadth and relative successes of the CRSs, its absence in government discussions surrounding proposals for a new sponsorship program is surprising. Our research could not find any reference to the cRss in relevant government papers or policies. The very different framing of the programs, and the political context into which the CPP and CSP were proposed-of deterrence and control rather than reception and integration-goes some way to explaining this absence. This section outlines the contemporary community sponsorship programs, highlighting the broader political framing of both the purpose and potential of the CPP and CSP. 39

Prior to the introduction of the CPP, the Commonwealth government expressed interest in a community sponsorship program in its 2012 budget and released a discussion paper examining the "feasibility of a pilot which would enable organisations to propose a person, in a humanitarian situation, for entry to Australia under the Humanitarian Program." 40 More than sixty submissions were received in response to the paper, from humanitarian organizations, faith-based groups, community organizations, settlement service providers, and state and local governments. ${ }^{41}$ In addition to receiving submissions, in August 2012 the Department of Immigration conducted two formal meetings with representatives from refugee advocacy and settlement organizations and community and faith-based organizations. They also held informal meetings and discussions. ${ }^{42}$ The government did not make any of the outcomes or recommendations of this approximately six-month consultation period publicly available. Notably, the submissions to the 2012 discussion paper were not published, despite publication being the usual practice.

As these consultations were taking place, the government commissioned the report of the Houston Expert Panel on Asylum Seekers. In this period, the number of refugees arriving by boat to Australia had reached record highs, 43 and the Labor government was cast by media outlets as "losing control" of the border. 44 The expert panel was charged with producing a report on "how best to prevent asylum seekers risking their lives by travelling to Australia by boat." 45 Whilst commissioned as an independent report, the document was broadly seen as means to enable the Labor government to re-establish third-country processing, despite fulfilling an election promise to end offshore detention and repealing the policy in 2008. The 2012 re-establishment of Australianfunded detention centres in Papua New Guinea and Nauru in order to provide a "circuit breaker to the current surge in irregular migration to Australia" was the most immediate and significant outcome of the report. ${ }^{46}$ However, the panel also made a range of recommendations on Australia's humanitarian program more broadly, and directly addressed the possibility of private humanitarian sponsorship.

In the context of addressing the costs associated with the panel's recommended expansion of Australia's "orderly" offshore humanitarian intake, ${ }^{47}$ the report suggested, 
Private and community sponsorship within Australia's humanitarian program could provide some important opportunities to assist with its expansion in a productive, cost-effective and communitybased way. It is important that the private and community sponsorship arrangements be responsibly utilised to their full potential. The panel expects that it may be possible to develop a sponsorship model that reduces the costs of a place under the humanitarian program by up to one-third and considers that any savings achieved through such an initiative should be used to offset other costs under the expanded program. 48

In this and its other recommendations, the focus of the report was not on just the implementation of measures to "expand regular humanitarian pathways," but also the "creation of disincentives" to irregular maritime migration that are "immediate and real" - and, by implication, punitive in their effect. 49 These objectives formed the political context in which the CPP was designed and introduced. The prospect of reducing the cost of the humanitarian program through sponsorship and the promotion of regular, "controlled" migration pathways were recurring themes in the introduction of the CPP and the subsequent CSP.

In the same period, the government further limited access to any meaningful form of family reunion for refugees arriving without authorization. As noted above, sHP has become the primary means by which refugee entrants are able to access family reunion in Australia. Alongside the barriers of high costs and prohibitively long delays, ${ }^{50}$ refugees who arrived in Australia by boat after August 2012 have no access to any form of family sponsorship, and later, in 2016, applications made by those who arrived by boat before this date were directed to be given the lowest processing priority. ${ }^{51}$ These policies, directed towards "irregular" arrivals, reinforce concerns discussed below that private sponsorship in Australia is an expensive, proxy form of family reunion and exploits the undersupply or absence of other family reunion pathways. ${ }^{22}$ Moreover, it is well recognized that other migration pathways for family reunion such as partner, child, and parent visas are out of reach for many refugees due to their high visa applications costs, stringent eligibility criteria, or simply because some visas are subject to extremely prolonged waiting periods.

When the CPP was formally announced in mid-2013, it constituted Australias first program for the full private sponsorship of humanitarian entrants by individuals, businesses, or community organizations. ${ }^{53}$ Humanitarian entrants, for the purposes of the CPP and the subsequent CSP, are defined as refugees or persons outside of their home country who are subject to gross violations of their human rights. The pilot was to provide for up to 500 places per annum within the offshore component of Australia's humanitarian program, rather than in addition to existing humanitarian commitments. ${ }^{54}$ Sponsors could participate in the program only via organizations selected and approved by the Department of Immigration, known as Approved Proposing Organisations (APOS). APOS were responsible for proposing an applicant and managing the sponsorship application, as well as ensuring sponsors were able to meet the costs of sponsorship and resettlement. Under the pilot, there were five recognized APOS, four of which were based in two Australian states (New South Wales and Victoria). 55 The costs of sponsorship, which we discuss further below, included a fee paid to APOS for their services.

The first CPP applications were lodged in October 2013, and the first visas granted in February 2014..$^{56}$ Notably, under the CPP, while sponsorees were required to meet the definition of a humanitarian entrant, and CPP applicants were prioritized over the sHP entrants, ${ }^{57}$ applicants were not selected or prioritized on the basis of evidence of a job offer, English-language skills, or age. Over the course of the 201314 financial year, 154 applications were received under the CPP, representing 570 individuals. Over the same period, 245 visas were granted under the CPP. ${ }^{58}$ Between the lodgement of the first applications under the CPP in October 2013 and the review of the program on 29 March 2015, 305 applications had been received under the pilot, representing more than 1,100 individuals. Over this period, 667 visas were granted under the CPP. Both demand for the program and the limited number of places resulted in the program being "consistently oversubscribed," and even though capacity to integrate was not a formal priority, in 2016 the government reported that over 61 per cent of places were awarded to applicants under forty. 59 The highest number of applications and grants were made in relation to sponsorees from Syria, followed by Iraq. Other visa grants were made to individuals from Afghanistan, Eritrea, and Somalia. ${ }^{60}$

In 2015 the government sought public submissions in a review of the CPP. Under the heading "What happens next?" the paper noted that "community feedback through this discussion paper will inform government considerations on the feasibility and possible model of a Community Support Programme." 61 Once again neither the submissions in response to the discussion paper, nor the government's view of the submissions, was made public. Of the submissions that were published by the submitting organizations, the consensus in the nature of the concerns raised about the CPP and in the accompanying recommendations for reform is noteworthy. In data released to the authors under Freedom of Information laws, the government's own summary of public submissions noted that thirteen out of seventeen respondents recommended that the CPP operate in addition to the existing humanitarian program; that "stakeholders" 
supported retaining the standard humanitarian eligibility criteria (rather than add new criteria such as capacity to work), and that "most organisations" submitted that visa application charges should be lowered. ${ }^{62}$

Despite government engagement of participating organizations and stakeholders in a formal consultation, not one of the above recommendations was incorporated into the final program. RCOA, the peak body for refugee organizations in Australia, noted in its representative submission to the inquiry that as a result of the high cost of the CPP, and its lack of additionality, the CPP's design risked undermining the humanitarian commitments of Australia's program and the potential of securing genuine community involvement in "community" sponsorship. ${ }^{63}$ In RCOA's annual consultations in 2016, many community members expressed concern that the CSP was accessible only to those who could afford to pay the high fees. ${ }^{64}$

In spite of these concerns, when the CSP was announced in 2017, the legal frameworks that governed the program more or less mirrored the design of the CPP, albeit with an entirely new set of selection criteria and higher fees. The most significant changes to the policy included an increased annual quota of sponsored places to 1,00o per annum from the previous 500, though again without an increase in Australia's overall offshore humanitarian intake, and the announcement that priority would be given to applicants meeting specific criteria on age, language skills, capacity to work, and the government's own "resettlement priorities." At the time of writing, implementation of the permanent CSP program is still in very early stages. Eleven APOs were announced in early 2018,65 and in May 2018 the CSP was tracking not to fulfill the quota for the $2017-18$ financial year. ${ }^{66}$

\section{Critiques of the Community Support Program}

Despite the claim that it draws from the experience of Canada's private sponsorship program, ${ }^{67}$ Australia's csp does not enhance or expand Australia's refugee resettlement program. Instead, the program is best understood as an exercise in the privatization of resettlement responsibilities and costs, which preserves a policy of strict government control over the terms of refugee entry and resettlement. Instead of taking into account community views, the Australian government appears to have heeded assessments of the CPP model as a "credible means" of providing humanitarian support "without placing additional strain on the Commonwealth budget." 68 As noted, and unlike Canada, the csp quota of 1,00o places is not additional to the government's Refugee and Humanitarian Program (RHP). This means that each sponsored refugee takes a place away from the government's own resettlement commitment. In 2013 the Australian government announced that it would increase the RHP quota from 13,750 to 18,750 in
2018-19, including 2,750 places reserved for in-country asylum applicants. ${ }^{69}$ However, with the introduction of the CsP, it became clear that this increase would be offset by 1,000 places set aside for private sponsors. As such, the CSP can be seen as a way to outsource the government's commitments, exploiting the community's good will, or, as is more often the case, a family's desperation. ${ }^{70}$

Indeed, the CSP has been promoted by the Australian government as a means to create "a sustainable model of private sponsorship for refugees that minimises costs to governments." ${ }^{71}$ According to governmental estimates, the program "will provide a revenue gain to the budget of \$26.9 million" over the first four years. ${ }^{72}$ This revenue gain comes from the high costs of the visa fees, including a AU $\$ 2,740$ non-refundable application fee and a second instalment fee of $\mathrm{AU} \$ 16,444$ for the main applicant and $\mathrm{AU} \$ 2,680$ for each secondary applicant (family member). ${ }^{73}$ In addition to visa fees, sponsors are required to pay fees to the APO. These fees are not fixed or regulated by the Australian government and are as high as approximately AU $\$ 20,000$, per application. ${ }^{74}$ Sponsors are also required to cover the costs of airfares and medical checks prior to arrival. Most notably the visa application charges do not directly cover or fund the cost of the applicant's resettlement. That is, they are simply transaction fees paid to the Australian government that are not attached to any clear service provided by the government to the humanitarian migrant or sponsor. ${ }^{75}$ Once the sponsored refugee has arrived, sponsors are required to cover all living costs and settlement support for the first year, or otherwise repay the government for any use of social security benefits through an Assurance of Support arrangement. ${ }^{76}$ All together, these fees and payments could total over AU\$100,00o for a refugee family of five, as shown in table 2.

Beyond the cost of sponsorship, the CsP adds further eligibility criteria that were not present in the CPP, which, read together, discriminate in favour of economically self-sufficient and easy-to-integrate humanitarian entrants. Under the CSP, applicants must be what we describe as "job ready," including being between the ages of eighteen and fifty, having "functional English," and "a job offer or skills to enable you to get a job quickly."77 Despite the fact that sponsors bear the costs of resettlement, priority is given to CSP applicants from countries that the government deems as "resettlement priorities." The precise details are unclear. However, the government has confirmed that priority is given to refugees from select countries, including "Democratic Republic of Congo, Afghanistan, Eritrea, Ethiopia, Myanmar, Bhutan, Syria and Iraq." 78 While other refugees are not formally excluded, they have been told that their applications "are highly unlikely to be considered, let alone accepted."79 As well, although refugees from these regions are indeed priority areas for UNHCR, 
Table 2. Fees and costs under the CSP

\begin{tabular}{lll} 
Stage & Fee & Cost \\
\hline Stage A & APO Expression of Interest fee & $\$ 275$ \\
Stage B & APO fee & $\$ 3,410$ \\
Stage C & APO fee & $\$ 3,190$ \\
& First Visa Application Charge (to the Australian & $\$ 2,740$ \\
& government) & \\
Stage D & APO fee & $\$ 5,865$ \\
& Second Visa Application Charge (to the Australian & $\$ 16,444$ (+\$2680 per each additional applicant) \\
& government) & \\
Stage E & APO bond & $\$ 5,000$ (may be refundable) \\
& Humanitarian Settlement Support fee & $\$ 611$ per person \\
& Assurance of Support Program & The cost of social security use over the first year, which \\
& & can be up to $\$ 17,513.60$ for an individual or $\$ 42,595.28$ \\
& & for a family of five \\
Other & Airfares, pre-departure medical screenings, and costs & Costs vary \\
costs & associated with settlement support & \\
Total & Individual & $\mathbf{\$ 5 5 , 0 4 8}$ \\
& Family of five & $\mathbf{\$ 9 3 , 2 9 4}$ \\
\hline
\end{tabular}

Source: AMES Australia, "Frequently Asked Questions (FAQs)," https://www.ames.net.au/csp/faqs.

Note: This is an example based on a specific APO's service charges. Precise APO fees differ between organizations, but visa application fees remain consistent.

these priorities have been set by the Australian government, and no reason has been provided for why other groups are deprioritized.

Aside from the age criterion, the requirements set out above are broadly stated and vague, and it is unclear how the criteria are being interpreted and applied. Indeed, questions of definition and interpretation arise acutely in the "workready" requirement. The government has confirmed that "priority [will be] given to applicants who have an employment offer" and to "applicants willing to live and work in regional Australia." 80 But in the absence of an employment offer, it is difficult to ascertain exactly who will be deemed to be job ready. Indeed, while the government envisions that the program will be taken up by corporate sponsors as part of their "corporate social responsibility" principles, this is yet to be seen. Indeed, it is much easier and cheaper for businesses to invest in and support refugees already in Australia, rather than pay significant fees to sponsor new refugees who are not guaranteed to be accepted and may take years to arrive. Feedback from APOs suggests that the only businesses involved in the CSP are those run by refugee communities themselves, through offers of employment to sponsored family members.
The overall profile of an eligible applicant confirms that the program is not designed, as a matter of priority, to resettle the most vulnerable or at-risk refugees and humanitarian applicants. ${ }^{81}$ The program certainly does not aim to accommodate "doubly disadvantaged" entrants, as was the case under the CRss. The considerable definitional scope of the criteria and the emphasis on government resettlement priorities confirms that the government will retain high levels of discretion in selection. Certainly the elderly, those without "relevant qualifications," and those without English-language skills are unlikely to be viable candidates for sponsorship under the program. As well, there are clear gendered implications in the criteria. The "job ready" requirement means that female-headed households and those with major care responsibilities are less likely to qualify as primary applicants, and the criteria are also likely to compound women's uneven access to, or outright exclusion from, education and work in some countries of origin.

In its review of the CPP, the Australian government suggested that as a result of sponsorees' limited access to statefunded support services, private sponsorship may not be the most appropriate avenue for highly vulnerable applicants for whom services may be more "appropriately provided by 
government-funded settlement service providers." ${ }^{82}$ While there is merit to this view, in the same breath the government confirmed that the processing of privately sponsored applications would be "assessed with high priority, wherever possible" to encourage sponsors to participate in the CSP "as a resettlement option over, or in addition to, other resettlement options through the standard humanitarian program." 83 It is the cumulative effect of these factors that forms the basis of our critique. Resettlement places are being allocated away from vulnerable applicants, and those places are simultaneously being prioritized ahead of other refugee applicants.

Even in cases where applicants are not uniquely vulnerable but have "commonplace" resettlement needs, a related concern is the lack of clarity regarding how businesses and corporations might effectively act as sponsors. In 2017 Assistant Minister for Immigration and Border Protection Alex Hawke said that the program was a chance for businesses to fulfill their corporate social responsibility rather than merely a costsaving measure. ${ }^{84} \mathrm{He}$ explained that "the idea is of course to have that support there provided by business groups who may know refugees in different camps, who they want to bring out [to Australia] who have the skills." 85 While the government has clearly emphasized the potential of businesses to meet corporate social responsibility targets through sponsorship, uptake of the program by businesses is unlikely to be strong without the careful and long-term establishment of relationships between refugee organizations, local refugee networks, and business communities. Further, the high costs of the program are likely to be a disincentive for businesses considering supporting refugees. As the Community Refugee Sponsorship Initiative (CRSI) has noted, while businesses may play a vital role in a sponsorship program, they are not well placed to directly sponsor refugees or to "provide ongoing settlement support and assistance for sponsored refugees." 86

A final concern with the current CsP model is the lack of a truly community-orientated settlement program. Sponsors are not required to form a sponsorship group, meaning that individuals can act as sponsors. As refugee advocacy organizations predicted in the discussion paper for the $\mathrm{CSP}_{,}{ }^{87}$ the lack of a criteria for wider community participation has meant that the CSP has again become an expensive yet expedited family reunion program for those desperate to get their family to safety. According to information provided by an APO, over 90 per cent of applications under the CsP have come from individual family members.

Because there is an insufficient number of family reunion pathways for refugees in Australia, ${ }^{88}$ the CSP offers those who can afford it a way to fast-track their family reunion application. While the lack of family reunion pathways in Australia must be addressed, ${ }^{89}$ the current csp risks becoming a privatized and extortionately expensive family reunion program rather than a model that utilizes the social capital and support of the wider Australian community. Feedback from APOs suggests that this is already the case, with over 90 per cent of applicants being family members of sponsors. A truly community-based sponsorship program should enable and encourage the wider community to be involved in settling refugees, rather than leaving it to a single family or family members.

\section{Private Sponsorship in Australia: A Cautionary Tale?}

As noted in our introduction, Australia is one of a number of states that have adopted or are adopting new programs for private or community sponsorship of refugees. Amongst the wide range of approaches to refugee sponsorship, Australia's program is unique insofar as it hijacks humanitarian places in order to allocate them into a privately funded resettlement program. By contrast, for example, New Zealand's recently introduced community sponsorship pilot, the Community Organisation Refugee Sponsorship Category, provides an additional twenty-five places to complement resettlement places from its quota. However, like the CSP, the eligibility criteria for the New Zealand pilot focus on individuals who have basic English-language proficiency, are between eighteen and forty-five years old, and have a minimum of three years' work experience or a qualification requiring a minimum of two years of tertiary study. ${ }^{\circ}$

Overall, the Australian and New Zealand approaches differ markedly from other community sponsorship models. The emphasis on employability and English-language proficiency arguably distorts the traditional focus on resettlement of the most vulnerable of refugees. Instead, these criteria allow states to claim that they are contributing to the global resettlement pool, while simultaneously using community sponsorship to reduce the cost of resettlement and increase their ability to select desired refugees. If other countries were to follow suit, this approach would have significant implications for resettlement principles and policy worldwide.

To address the concerns outlined above, in 2018 a group of leading civil society organizations in Australia formed a campaign group to advocate for a better community sponsorship model that harnesses the power of community support..$^{11}$ The Community Refugee Sponsorship Initiative (CRSI) is calling for the government to provide up 10,000 community-sponsored places per annum in addition to the refugee program, with no revenue-raising visa charges or APO fees. In order to foster community engagement in the settlement process, the CRSI has recommended that individuals can partner with a registered and suitably credentialed nonprofit association (an “Approved Community Organisation”), which will be responsible for raising funds to cover the costs 
of airfares, other initial settlement costs, and the first year of settlement. Sponsored refugees would have access to government social security benefits, the costs of which would be billed back to the sponsors by the government after the first year of settlement. The CRSI model will "reduce the cost of sponsoring a family of five from up to $\$ 100,000$ (under the CSP) to between $\$ 20,000$ and $\$ 50,000$, depending on the extent to which income support is required in the first year after arrival." 92 The initiative also advocates removal of any discriminatory selection criteria and the requirement for sponsored refugees to be job ready.

The model proposed by CRSI would bring Australia closer to the model of community sponsorship in Canada, where additionality is a key principle, and umbrella sponsorship agreement holders play a key role in mobilizing a broad base of community sponsors. The model would also move Australia closer to its historical roots under the CRSs, where the focus of the program was on community involvement in refugee resettlement and the provision of quality of settlement outcomes, rather than requiring the applicant to be "integration ready" with no government support.

A further issue to be considered when reforming community sponsorship is whether sponsors are able to name or select which refugees to sponsor. In Canada the ability to name refugees in the private sponsorship program has created an "echo effect," whereby those who are privately sponsored in turn use the program to sponsor family members. Over time, this has meant that private sponsorship is increasingly dominated by family reunification applications. ${ }^{93}$ In order to address the issue of community sponsorship places being predominantly used as a means of family reunification, Canada has introduced a Blended Visa Office-Referred (BVOR) Program. Under the BVOR, UNHCR refers vulnerable refugees to the Canadian government, and they are matched to sponsors, and the cost of settlement is split 50/50 between the sponsorship group and the government. The uptake of BVOR has been limited, and it remains to be seen whether the program can shift emphasis away from family reunification. ${ }^{94}$ The United Kingdom has taken a similar route. Under the Vulnerable Persons Resettlement Scheme (VPRS), UNHCR-referred refugees are matched with sponsorship groups. Sponsorship groups must have support from their local area government and must have an approved settlement plan to sponsor refugees. The criteria for resettlement under the BVOR and VPRS are based on vulnerability rather than other settlement criteria. Given the limited opportunities for family reunification in Australia, we suggest that considerable thought needs to be given to the relationship between family reunification and community sponsorship.

The family reunification issue and the csp's focus on jobready refugees points to a wider consideration central to the design and implementation of private sponsorship in all jurisdictions: the relationship between community sponsorship and complementary or alternative migration pathways. An obvious question is whether refugees who are readily employable ought to be supported by states through concessions that allow them easier access to regular skilled/labour migration pathways. Similarly, states could provide refugees with easier access to family migration under mainstream migration programs. In order to preserve the inherent focus of resettlement on vulnerable refugees, states should carefully consider the role of community sponsorship in the context of a suite of durable solutions available to refugees. In the context of the CSP, it is reasonable to ask whether, as a matter of principle, Australia's skilled migration program could be amended to achieve similar outcomes without intrusion into Australia's humanitarian program.

\section{Conclusion}

Under the banner of the militarized joint-agency taskforce Operation Sovereign Borders, and through implementation of a series of aggressive non-entrée policies, including asylum boat turn-backs, Australia has prevented the arrival of onshore asylum seekers in favour of its "managed" refugee resettlement program. Simultaneously, the Australian government has attempted to promote the CSP as a complementary pathway for refugee protection. However, rather than being "in addition," as promised when announced at the New York Leaders' Summit on Refugees, the csP does not complement or expand Australia's humanitarian program. Rather, the program represents a continuation of the government's policies of refugee deterrence and control. Indeed, when Prime Minister Turnbull announced the CsP at the 2016 summit, he stated, "Because we have control of our borders, we are able to deliver that generous humanitarian programme." 95

This agenda of control is further pursued through the eligibility criteria for CSP, which seeks to cherry-pick "job ready" refugees with high integration capacity from preferred countries of origin. In addition, the Australian model of private sponsorship reduces the government's financial commitment to humanitarian resettlement in real terms. Unlike other programs, it requires sponsors to pay fees that bear no clear or direct correlation with the real costs of resettlement. The costs of participating in the program are not merely prohibitive but, somewhat surprisingly, have been characterized by the government as a revenue-raising measure. These features of the cSP critiqued in this article are not minor details within the overall program. They reveal the core neoliberal principles of economic rationalization and market-driven privatization of public services, guiding private sponsorship in Australia. Given these elements of the 
CSP, which outsource and economically rationalize humanitarian resettlement, it is difficult to comprehend how it will realize the government's apparent other objective for private sponsorship, of providing additional pathways to protection and "building on the goodwill that exists in communities" towards the resettlement of humanitarian entrants. ${ }^{96}$

At a time when community sponsorship is emerging as a pillar to expand access to durable solutions for refugees, Australia's experimentation and practice is significant in shaping the normative understanding of community sponsorship vis-à-vis refugee resettlement. This article has argued that Australia's recent experimentation and practice through the CSP provides a cautionary tale. As the CsP experience shows, there are real risks that states could utilize community sponsorship as an instrument to control refugee movements and to hijack traditional government-led and vulnerabilitybased refugee resettlement by privatizing their obligations. This redistribution of resettlement places has occurred while Australia has simultaneously sought to reduce reliance on UNHCR-referred refugees and give priority to Christian refugees. ${ }^{97}$ If community sponsorship is to fulfill its promise to enhance refugee protection, these risks must be addressed and avoided in the implementation of programs in all resettlement states.

\section{Notes}

1 UnHCR, Global Compact on Refugees, Final Draft, June 2018, 18, http://www.unhcr.org/en-au/events/ conferences/5b3295167/official-version-final-draft-globalcompact-refugees.html.

2 Malcolm Turnbull, news release, 21 September 2016, http://web.archive.org/web/20180417071206/https://www. pm.gov.au/media/leaders\%E2\%80\%99-summit-refugees.

3 Operation Sovereign Borders, https://osb.homeaffairs.gov. $\mathrm{au} /$. For commentary, see Asher Lazarus Hirsch, “The Borders beyond the Border: Australia's Extraterritorial Migration Controls," Refugee Survey Quarterly 36, no. 3 (2017): 48.

4 The "principle of additionality ensures that private efforts expand refugee protection spaces by complementing government commitments to resettlement": Jennifer Hyndman, William Payne, and Shauna Jimenez, "Private Refugee Sponsorship in Canada," Forced Migration Review 54 (2017): 59. On the "interpretive malleability" of the concept, see also Shauna Labman, "Private Sponsorship: Complementary or Conflicting Interests?" Refug 32, no. 2 (September 2016): 67-80.

5 Farida Fozdar and Lisa Hartley, "Refugee Resettlement in Australia: What We Know and Need to Know," Refugee Survey Quarterly 32, no. 3 (September 2013): 23-51, https://doi.org/10.1093/rsq/hdtoo9; Maria O'Sullivan, “The Ethics of Resettlement: Australia and the
Asia-Pacific Region," International Journal of Human Rights 20, no. 2 (2016): 241-63 https://doi.org/10.1080 /13642987.2015.1103523; Sahar Okhovat, Asher Hirsch, Khanh Hoang, and Rebecca Dowd, "Rethinking Resettlement and Family Reunion in Australia," Alternative Law Journal 42, no. 4 (December 2017): 273-8, https://doi .org/10.1177/1037969X17732705.

6 Department of Immigration, Local Government and Ethnic Affairs, "Our Good Friends": Australians Helping Refugees to a New Life (Sydney: Department of Immigration, Local Government and Ethnic Affairs, 1991), 62. During the 1980 os and into the early 1990 s the CRSs provided settlement support to all of Australia's major cohorts of resettlement arrivals, in parallel to government settlement services, including migrant centres and hostels.

7 Michael MacKellar, minister for immigration and ethnic Affairs, "Refugee Council Calls for Community Understanding and Support," news release, 157/79, 30 October 1979. The Australian Refugee Advisory Council was established to provide advice to the minister on movement to and settlement in Australia of refugees from all sources. At its first meeting, the committee "recommended the adoption of a comprehensive program to assist refugees from wherever they may come to settle in Australia."

8 Michael MacKellar, minister for immigration and ethnic affairs, "Immigrants or Refugees" (paper presented at the Australian Institute of International Affairs Seminar, Sydney, 19 August 1978).

9 For an overview of the policy during this period, see Claire Higgins, Asylum by Boat: Origins of Australia's Refugee Policy (Sydney: NewSouth Publishing, 2017).

10 MacKellar, "Immigrants or Refugees," 16.

11 Ms Keys Young Planners, An Evaluation of the Community Refugee Settlement Scheme, prepared for Department of Immigration and Ethnic Affairs, 1981, 3.

12 Ian Macphee, minister for immigration and ethnic affairs, "Extension of CRSs to East European Refugees," news release, 166/80, 8 December 1980.

13 Department of Immigration and Ethnic Affairs, "Community Hosting and Friendship Scheme and Community Refugee Settlement Scheme: Information for Individuals, Groups and Organisations Wishing to Assist in the Settlement of Refugees in the Community" (1979).

14 Department of Immigration and Ethnic Affairs, A Handbook for Support Groups Participating in the Community Refugee Settlement Scheme, 2nd ed. (Canberra: Australian Government Publishing Service, 1983), 1.

15 Department of Immigration and Ethnic Affairs, Handbook, 5. 16 In 1980 this committee comprised representatives from Migrant Settlement Council of Nsw, Local Government Shires Association, Australian Jaycees, Uniting Church of Australia, St Vincent de Paul Society, Department of Immigration and Ethnic Affairs, Lao Community, Indochinese Refugee Association Inc., Care Force, and Nsw Adult Migrant Education Service. 
17 Department of Immigration, Local Government and Ethnic Affairs, "Our Good Friends," 52. Organizations involved in the CRss at its inception included the St Vincent de Paul Society, the Spencer Gulf Refugee Resettlement Committee, Our Lady Help of Christians Parish, the Catholic Diocese of Port Pirie, the Anglican Church Diocese of Willochra, the Uniting Church, APEx Club, and the Whyalla Chambers of Commerce and the Soroptimist Club of Whyalla.

18 Department of Immigration and Ethnic Affairs, Handbook, 5 .

19 Sue Ingram, assistant secretary Settlement Branch, to regional directors, 15 March 1983, Community Refugee Settlement Scheme Policy and Plan, NAA A446 1983/76959.

20 Okhovat et al., "Rethinking Resettlement," 274.

21 Ingram to regional directors.

22 Dario Castello to migration officers and Overseas Post, 13 December 1986, Community Refugee Settlement SchemeProgram Management, NAA A446 1986/75554, 5.

23 Castello to migration officers.

24 Sue Ingram, assistant secretary Settlement Branch, to D. Wheen, regional director North Asia, Hovng Kong, 15 March 1983, 3, Community Refugee Settlement Scheme Policy and Plan, NAA A446 1983/76959. Overseas posts were urged to consider only those "disadvantaged" cases that would benefit from additional cRss support but also to ensure that cases were not "so difficult" that they would burn out sponsor groups and deter them from further sponsoring.

25 Department of Immigration and Ethnic Affairs, Community Refugee Settlement Scheme: Information for Organisations, Groups and Individuals Who Wish to Help Refugees Settle in the Community, 2nd ed. (Canberra: Australian Government Publishing Service, 1983). This equates to roughly AU $\$ 860$ per person or $\mathrm{AU} \$ 2281$ for a family of four based on Reserve Bank of Australia calculations. See Reserve Bank of Australia, "Inflation Calculator," https:// www.rba.gov.au/calculator/annualDecimal.html.

26 Michael MacKellar, "Community Refugee Settlement Scheme," news release, 173/79, 3 December 1979.

27 Department of Immigration, Local Government and Ethnic Affairs, "Our Good Friends," 52.

28 Msj Keys Young Planners, Evaluation; Peter Hanley, Evaluation of the Community Refugee Settlement Scheme (CRSS) in North Queensland (Queensland: Indochinese Refugee Association of Queensland, 1983).

29 Ms Keys Young Planners, Evaluation.

30 MS Keys Young Planners, Evaluation, 168.

31 Msj Keys Young Planners, Evaluation; Hanley, Evaluation.

32 Australian National Audit Office, "Provision of Migrant Settlement Services by DIMA," Audit Report No. 29, 1998-9, 84-8.

33 Australian National Audit Office, Provision of Migrant Settlement Services. For example, an audit of files held in state and territory offices indicated information on validation of groups' financial and other resources was not well documented. Further, in relation to monitoring it was found that, while DIMA procedures required regular monitoring of sponsorships, the department had not systematically monitored with the required frequency.

34 Refugee Council of Australia, "Submission to 1999 Review of Material Assistance to Humanitarian Program Entrants," 1999, 6-7.

35 Urbis Keys Young, "Evaluation of the Integrated Humanitarian Settlement Strategy (IHSs)," prepared for Department of Immigration and Multicultural and Indigenous Affairs, 2003, 4.

36 Urbis Keys Young, "Evaluation."

37 Urbis Keys Young, “Evaluation.” Services available under the IHss included initial orientation and assistance, accommodation support, provision of household goods, and health assessments.

38 Urbis Keys Young, "Evaluation," 5. A subset program of the IHss was called the Community Support for Refugees, and groups were eligible to receive support and training.

39 Department of Immigration and Ethnic Affairs, Handbook, 1983.

40 Minister for Immigration and Citizenship, "Explanatory Statement: Migration Amendment Regulation 2013 (No 2) (Select Legislative Instrument 2013 No. 75)," Parliament of Australia, 1 June 2013, 2. Interestingly, as early as 2009, the Refugee Council of Australia was asked to advise the government on several questions: "What role should the community, business and local governments have in resettling refugees under the offshore Humanitarian Program? What role might private sponsorship play?" Correspondence on file with authors.

41 Minister for Immigration and Citizenship, "Explanatory Statement," 2.

42 Minister for Immigration and Citizenship, "Explanatory Statement," 2-3.

43 Janet Phillips, "Boat Arrivals and Boat 'Turnbacks' in Australia since 1976: A Quick Guide to the Statistics," Parliamentary Library Research Paper Series, September 2015. The arrival numbers remain small, compared to many other states of first asylum. However, in the 2012-13 financial year, 25,143 asylum seekers arrived by boat, compared to 7,983 arrivals and 4,730 arrivals in the preceding two years.

44 Emma Griffiths, "Illegal' Arrivals Have Reached 50,000 under Labor: Abbott,” ABC News, 7 August 2013, http:// www.abc.net.au/news/2013-08-07/abbott-says-asylumseeker-arrivals-now-500oo-under-labor/4871506.

45 Expert Panel on Asylum Seekers, "Report of the Expert Panel on Asylum Seekers," Australian Government, 13 August, 2012, 9.

46 Migration Legislation Amendment (Offshore Processing and Other Measures) Act (2012); Expert Panel, "Report," 47.

47 Expert Panel, "Report," 39.

48 Expert Panel, "Report," 40 (emphasis added).

49 Expert Panel, "Report," 13. 
50 Refugee Council of Australia, "Addressing the Pain of Separation for Refugee Families," November 2016, https:// www.refugeecouncil.org.au/publications/reports/familyseparation/\#read-report; Okhovat et al., "Rethinking Resettlement."

51 Ministerial Direction No 72: Order for Considering and Disposing of Family Visa Applications, September 2016. See also Okhovat et al., "Rethinking Resettlement."

52 See Okhovat et al., "Rethinking Resettlement."

53 Brendan O'Connor, minister for immigration and citizenship, "Community Refugee Sponsorship Trial Begins," news release, 3 June 2013.

54 Department of Immigration and Border Protection, "Australia's Humanitarian Programme Information Paper," December 2013, 8.

55 Department of Immigration and Border Protection, "Australia's Humanitarian Programme," 8.

56 Department of Immigration and Border Protection, "Community Support Programme Discussion Paper," June 2015, 13.

57 Refugee Council of Australia, "Submission: Community Support Program Consultation," July 2015, https://www. refugeecouncil.org.au/wp-content/uploads/2015/o7/1507csp.pdf.

58 Department of Immigration and Border Protection, "Community Support Programme Discussion Paper," 13.

59 Australian Government Productivity Commission, "Migrant Intake into Australia: Productivity Commission Inquiry Report," 13 April 2016, 32.

60 Department of Immigration and Border Protection, "Community Support Programme Discussion Paper," 13.

61 Department of Immigration and Border Protection, "Community Support Programme Discussion Paper," 11.

62 Department of Home Affairs, Freedom of Information Section, Request FA18/05/00515, 3 December 2018, on file with authors.

63 Refugee Council of Australia, "Submission."

64 Refugee Council of Australia, "Intake Submission on Australia's 2016-2017 Refugee and Humanitarian Program," 29 March 2016, 44, https://www.refugeecouncil.org.au/ intake-sub-2016-2017/.

65 Department of Home Affairs, "Community Support Program: Frequently Asked Questions," 1 July 2018, https:// webarchive.nla.gov.au/awa/20180615234052/https://www .homeaffairs.gov.au/Refugeeandhumanitarian/Documents/ csp-faq.pdf.

66 Commonwealth, Legal and Constitutional Affairs Legislation Committee, Senate, 22 May 2018, 119 (Geddes).

67 Department of Immigration and Border Protection, "Community Support Programme Discussion Paper," 13.

68 Ernest and Young, "Evaluation of the Humanitarian Settlement and Complex Case Support Programmes," prepared for the Australian Department of Social Services, 2016, 31.

69 Lyndal Curtis, "Refugee Intake to Rise by 7,500 over Four Years as Government Negotiates to Resurrect Temporary
Protection Visas," ABC News, 3 December 2014, http:// www.abc.net.au/news/2014-12-03/refugee-intake-to-riseby-7,500-places-over-four-years/5936614.

70 Refugee Council of Australia, "The Community Support Program: Providing Complementary Pathways to Protection or Privatising the Humanitarian Program?," 4 July 2017, https://www.refugeecouncil.org.au/ community-support-program-brief/.

71 Alex Hawke, "Turnbull Government Announces Community Support Programme," 6 May 2017, https://webarchive. nla.gov.au/awa/20180615101808/http://minister.homeaffairs.gov.au/alexhawke/2017/Pages/community-supportprogramme.aspx.

72 Janet Phillips and Harriet Spinks, "Immigration and Border Protection Overview," Parliamentary Library, Parliament of Australia, https://www.aph.gov.au/About_Parliament/Parliamentary_Departments/Parliamentary_Library/pubs/rp/ BudgetReview201718/Immigration\#_ftn9.

73 Department of Home Affairs, "Fees and Charges for Other Visas," last updated 1 July 2019, https://immi. homeaffairs.gov.au/visas/getting-a-visa/fees-and-charges/ current-visa-pricing/other.

74 AMES Australia, "CsP Businesses and Organisations: Register Your Interest," https://www.ames.net.au:443/csp/ victoria.

75 The government has described the VAC as offsetting "the costs to the government for support services available to humanitarian entrants" after arrival in Australia such as "Medicare and some employment services": Commonwealth of Australia, Senate Estimates, 23 May 2017, 120 (David Wilden).

76 Department of Social Services, "Assurance of Support," 14 June 2018, https://www.dss.gov.au/about-the-department/ international/policy/assurance-of-support.

77 Department of Home Affairs, “The Community Support Program," last updated 16 June 2018, https://webarchive. nla.gov.au/awa/20180615142550/https://www.homeaffairs. gov.au/trav/refu/offs/community-support-program. In reporting to Parliament on the early stages of the CSP, a departmental spokesperson stated that most of those "primary applicants had a direct job offer," which "is exactly the intent of the program": Commonwealth, Legal and Constitutional Affairs Legislation Committee, Senate, 22 May 2018, 117 (Mansfield).

78 Parliament of Australia, "Legal and Constitutional Affairs Legislation Committee, Estimates, Department of Home Affairs," 22 May 2018, http://parlinfo.ap .gov.au/parlInfo/sea rch/display/display.w3p; query $=\mathrm{Id} \% 3 \mathrm{~A} \% 22 \mathrm{committees} \% 2 \mathrm{Festimate}$ \%2F75507344-48f1-4665-8f23-623c6eb5c2od\%2Fooo2\%22.

79 Ben Doherty, "South Sudan, Somalia and Iran Excluded from One of Australia's Refugee Programs," Guardian, 4 April 2018, http://www.theguardian.com/australia-news/ 2018/apr/o5/south-sudan-somalia-and-iran-excludedfrom-one-of-australias-refugee-programs. 
80 Department of Home Affairs, "Community Support Program."

81 On this point, see Refugee Council of Australia, "Submission."

82 Department of Immigration and Border Protection, "Community Support Programme Discussion Paper," 7.

83 Department of Immigration and Border Protection, "Community Support Programme Discussion Paper," 7.

84 Gabrielle Chan, "Budget Expected to Expand Sponsorship Program for Refugees-at Cost of \$40,000 Each," Guardian, 5 May 2017, https://www.theguardian.com/australianews/2017/may/05/budget-could-expand-private-sponsorship-program-for-refugees.

85 Chan, "Budget Expected to Expand Sponsorship Program."

86 Community Refugee Sponsorship Initiative, "A Better Way: A New Model for Community Sponsorship of Refugees in Australia," April 2018, http://www.ausrefugeesponsorship. com.au/wp-content/uploads/2018/o6/CRsI-Policy-BriefLong-April-2018.pdf.

87 Refugee Council of Australia, "Submission."

88 Okhovat et al., "Rethinking Resettlement."

89 Okhovat et al., "Rethinking Resettlement."

90 New Zealand Immigration, "Community Organisation Refugee Sponsorship Category Introduced," 21 December 2017, https://www.immigration.govt.nz/about-us/media-centre/ news-notifications/community-organisation-refugeesponsorship-category-introduced.

91 Community Refugee Sponsorship Initiative, http://www .ausrefugeesponsorship.com.au/.

92 Community Refugee Sponsorship Initiative, "A Better Way."

93 In Canada, between 2010 and 2014, "62\% of PSRs surveyed were sponsored by a member of their family." Immigration, Refugees and Citizenship Canada, "Evaluation of the Resettlement Programs (GAR, PSR, BVOR and RAP)," 7 July 2016, https://www.canada.ca/en/immigration-refugeescitizenship/corporate/reports-statistics/evaluations/ resettlement-programs.html\#toc1-2-1.

94 Shauna Labman and Madison Pearlman, "Blending, Bargaining, and Burden-Sharing: Canada's Resettlement Programs," Journal of International Migration and Integration 19, no. 2 (2018): 439-49.

95 Malcolm Turnbull, "Transcript of Doorstop Interview," 20 September 2016, https://parlinfo.aph.gov.au/
parlInfo/search/display/display.w3p;query=Id:\%22media/ pressrel/4830788\%22.

96 Department of Immigration and Border Protection, "Community Support Programme Discussion Paper," 6.

97 As Australian Prime Minister Malcolm Turnbull said to Us President Donald Trump, "We are very much of the same mind. It is very interesting to know how you prioritise the minorities in your executive order. This is exactly what we have done with the program to bring in 12,00o Syrian refugees, 90 per cent of which will be Christians. It will be quite deliberate and the position I have taken-I have been very open about it." ABC News, "Donald Trump and Malcolm Turnbull's Phone Call: The Full Transcript," 4 August 2017, http://www.abc.net.au/news/2017-08-04/donald-trumpmalcolm-turnbull-refugee-phone-call-transcript/8773422. See also A. Odysseus Patrick, "Australia’s Immoral Preference for Christian Refugees," New York Times, 20 January 2018, https://www.nytimes.com/2017/05/03/opinion/ australias-immoral-preference-for-christian-refugees .html; Refugee Council of Australia, "Less Than One Third of Refugees in Australia's Humanitarian Program Are Resettled from UNHCR," 14 July 2017, https://www.refugeecouncil .org.au/getfacts/seekingsafety/refugee-humanitarianprogram/less-one-third-refugees-australias-humanitarianprogram-resettled-unhcr/.

Asher Hirsch is a PhD candidate at Monash University and a senior policy officer at the Refugee Council of Australia. He can be contacted at asher.hirsch@monash.edu.

Khanh Hoang is a PhD candidate at the Andrew and Renata Kaldor Centre for International Refugee Law, University of New South Wales, and a senior protection assistant at the UNHCR Regional Representation of Canberra. The views expressed in this article are those of the author and do not necessarily reflect the views of UNHCR. He can be contacted at khanh.hoang@student.unsw.edu.au.

Anthea Vogl is a lecturer at the Faculty of Law at University of Technology Sydney. She can be contacted at Anthea.Vogl@ uts.edu.au. 